\title{
Past and future drought in Northwestern Algeria: the Beni Bahdel Dam catchment
}

\author{
Senna Bouabdelli ${ }^{1}$, Ayoub Zeroual ${ }^{1}$, Mohamed Meddi $^{1}$, Fateh Djelloul ${ }^{2}$, and Ramdane Alkama ${ }^{3}$ \\ ${ }^{1}$ Ecole Nationale Supérieure d'Hydraulique de Blida, L-GEE, 09000, Blida, Algeria \\ ${ }^{2}$ Ecole Nationale Supérieure d'Hydraulique de Blida, L-MVRE, 09000, Blida, Algeria \\ ${ }^{3}$ European Commission, JRC, Directorate D - Sustainable Resources, \\ Bio-Economy Unit, TP124 Via E. Fermi, 2749, 21027 Ispra (VA), Italy \\ Correspondence: Senna Bouabdelli (s.bouabdelli@ensh.dz)
}

Published: 16 September 2020

\begin{abstract}
In last decades, the impact of climate change started to appear in the semi-arid regions of the Mediterranean Basin. The severity and frequency of drought events in Northwestern Algeria have affected water resources availability and agriculture. This study aims to evaluate the temporal evolution of drought events characteristics, such as drought duration, frequency and severity, of the Beni Bahdel Dam catchment, Northwestern Algeria. Drought characteristics have been derived from the Standardized precipitation index (SPI) computed for the period from 1941 to 2100 using precipitation data from observations and simulations of the regional climate model RCA4 (Rossby Centre Atmosphere model, version 4). The RCA4 model was forced by the global circulation model MPI-ESM-LR under two Representative Concentration Pathways (RCPs) scenarios. The ability of the model simulations was firstly assessed to reproduce the drought characteristics from observed data (19512005). Then, future changes in drought characteristics over the twenty-first century were investigated under the two scenarios (RCP4.5 and RCP8.5). Results show an amplification of drought frequencies and durations in the future under the RCP8.5 scenario.
\end{abstract}

\section{Introduction}

In last decades, the impact of climate change started to appear in the Mediterranean basin. This change have caused enormous socio-economic damages, including water scarcity and drawdown of groundwater levels that has put rain-fed crops at risk. Marcos-Garcia et al. (2017) reported an increase in drought severity and duration in the southern part of the Mediterranean basin in the second half of the 20th century. Several studies also published drying trends in the Western Mediterranean region starting at different times, i.e. from the mid-1920's to 1950 and since the mid-1970's (Brunet et al., 2007; Zeroual et al., 2019). The vast plains of the western region of Algeria are an important agricultural production and farming zone. However, the Northwestern Algeria is particularly vulnerable area to climate change (Achour et al., 2020; Bouabdelli et al., 2020; Meddi et al., 2010; Zeroual et al., 2017). The severity and frequency of drought events in this region have affected water resources availabil- ity and agriculture and the trends to drier conditions seem to intensify. The western plains have suffered from a drastic reduction of rainfall by about $30 \%$ since 1975 (Meddi et al., 2010). This reduction caused negative impacts on water resources availability in several periods. The Beni Bahdel Dam, which is principally designed for the irrigation of the western plains and drinking supply, has attained its minimum level in several years failing to satisfy the water demand. This situation likely will intensify in the future, where there is consensus in projections by the International Panel on Climate Change (IPCC) about future decreases in rainfall (Christensen et al., 2007). Zeroual et al. (2019) have also confirmed this for the Northwestern part of the country using the output of 15 regional climate models (RCMs), as part of the CORDEX-Africa program (Coordinated Regional climate Downscaling Experiment). The climate in Northwestern Algeria was humid in 1951, semi-arid since 1973 and it is projected to be arid in 2100. Bouabdelli et al. (2020) also found that hydrological drought risk determined with 
frequency analysis likely will rise especially under RCP8.5 with higher severities and durations.

The above issues motivate this study, which is aimed to assess drought occurrence during the last decades and investigate their projected changes under future climate. The results can be helpful to establish an accurate warning tool for drought monitoring over the Beni Bahdel Dam catchment.

\section{Material and methods}

In this study, the Standardized Precipitation Index (SPI), Mckee et al. (1993) accumulated over 12 months was used to characterize drought events. The SPI-12 is considered to be an approximation of the state of the surface water volume (dams) and the groundwater level (aquifers) (Khan et al., 2008). The observed precipitation data used for this are coming from the Beni Bahdel basin located in the Northwest Algeria (Fig. 1). These data cover the period 1941-2010 and have a monthly time step. We used the computation procedure for SPI as defined by Mckee et al. (1993). For drought events characteristics, the period, during which the SPI value is continuously negative and reaches at least value of $(-1)$ or less is defined by Dracup et al. (1980) as drought duration $(D)$. The absolute sum of SPI values during this period $(D)$ was called drought severity $(S)$ or drought magnitude (Shiau, 2006).

We have also used in this study, simulations of the regional climate model RCA4 of SMHI at the horizontal resolution of roughly $0.44^{\circ}$, forced by the MPI-ESM-LR global circulation model and turned on the African region (Jones et al., 2011). The Simulated monthly precipitation data are provided by the CORDEX-Africa (Coordinated Regional climate Downscaling Experiment) initiative of the CMIP5 project for the World Climate Research Program (Giorgi et al., 2009).

Once the time series of the monthly precipitation were extracted from RCA4-MPI-ESM-LR model from 1951 to 2100, we proceeded to the future changes in drought characteristics according to the two following stages: the first step is to evaluate the ability of the RCA4-MPI-ESM-LR model simulations to capture drought events characteristics derived from the monthly observed precipitation, including, severity $(S)$ and duration $(D)$ during the period from 1951 to 2005 . We should note here that for this comparison, the monthly precipitation was not bias corrected. As a second step, we calculate the SPI-12 series and their characteristics for the far future (2045-2100) based on the projected monthly precipitation, under the two RCP scenarios (RCP4.5 and RCP8.5). The monthly-modeled precipitation used in this step has been corrected using the quantile-quantile (QQ) bias correction algorithm (Teutschbein and Seibert, 2012). The mathematical equations of the quantile-quantile (QQ) bias correction algorithm are detailed in Teutschbein and Seibert (2012).
Table 1. Number and mean severity and duration of drought events, and maximum severity and duration.

\begin{tabular}{lcrrcc}
\hline & $\begin{array}{c}\text { Number } \\
\text { of } \\
\text { events }\end{array}$ & $\begin{array}{r}D \\
\text { mean } \\
\text { (month) }\end{array}$ & $\begin{array}{c}S \\
\text { mean }\end{array}$ & $\begin{array}{c}D \\
\max \\
\text { (month) }\end{array}$ & $\begin{array}{c}S \\
\text { max }\end{array}$ \\
\hline $\begin{array}{l}\text { Observed } \\
1951-2005\end{array}$ & 25 & 14.04 & 11.75 & 59 & 68 \\
\hline $\begin{array}{l}\text { Historical } \\
1951-2005\end{array}$ & 30 & 10.69 & 8.95 & 59 & 75 \\
\hline $\begin{array}{l}\text { Observed } \\
1941-2010\end{array}$ & 36 & 11.36 & 9.11 & 59 & 68 \\
\hline $\begin{array}{l}\text { RCP4.5 } \\
2045-2100\end{array}$ & 38 & 10.34 & 8.92 & 47 & 63 \\
\hline $\begin{array}{l}\text { RCP8.5 } \\
2045-2100\end{array}$ & 49 & 7.45 & 8.4 & 58 & 70 \\
\hline
\end{tabular}

\section{Results and discussion}

The drought duration and severity have been derived from SPI-12 time series. Results are shown for the observed period 1941-2010 (Fig. 2a). As can be seen, there is trends towards dry conditions in the meteorological records since 1970, i.e. more negative SPI-12 values. The Beni Bahdel basin has experienced more severe drought episodes with longer durations since mid-1970s. The drought events attained its maximum severities during the periods 19821987 and 1995-2003.

Table 1 presents the number of drought events, the mean and maximum values of the duration and the severity of past and future drought events. The Beni Bahdel basin experienced 36 meteorological drought episodes; the maximum duration was 59 months for the drought that started in June 1996. The drought with the maximum severity (68) started in December 1981.

For the historical period, the SPI-12 data derived from the RCA4-MPI-ESM-LR climate model show similar drying trend in the period 1951-2005. Compared to the observed data, the model overestimates the number of drought events ( 30 versus 25 observed events) but with less severity (8.95 versus 11.75$)$ and duration events (10.69 versus 14.04 months) (Table 1). In addition, the model underestimated the median of the annual precipitation by $15 \%$. These results confirm the importance of noise investigation and bias correction in climate simulations (Alderlieste et al., 2014).

We should note that, for the future period, the SPI-12 obtained from the model simulation are calculated after bias correction for the two scenarios.

In the future, the number of drought events is predicted to remain about equal (38 months, RCP4.5). The mean number events under the most pessimistic scenario (RCP8.5) is projected to rise to 49 months, which means an increase by 

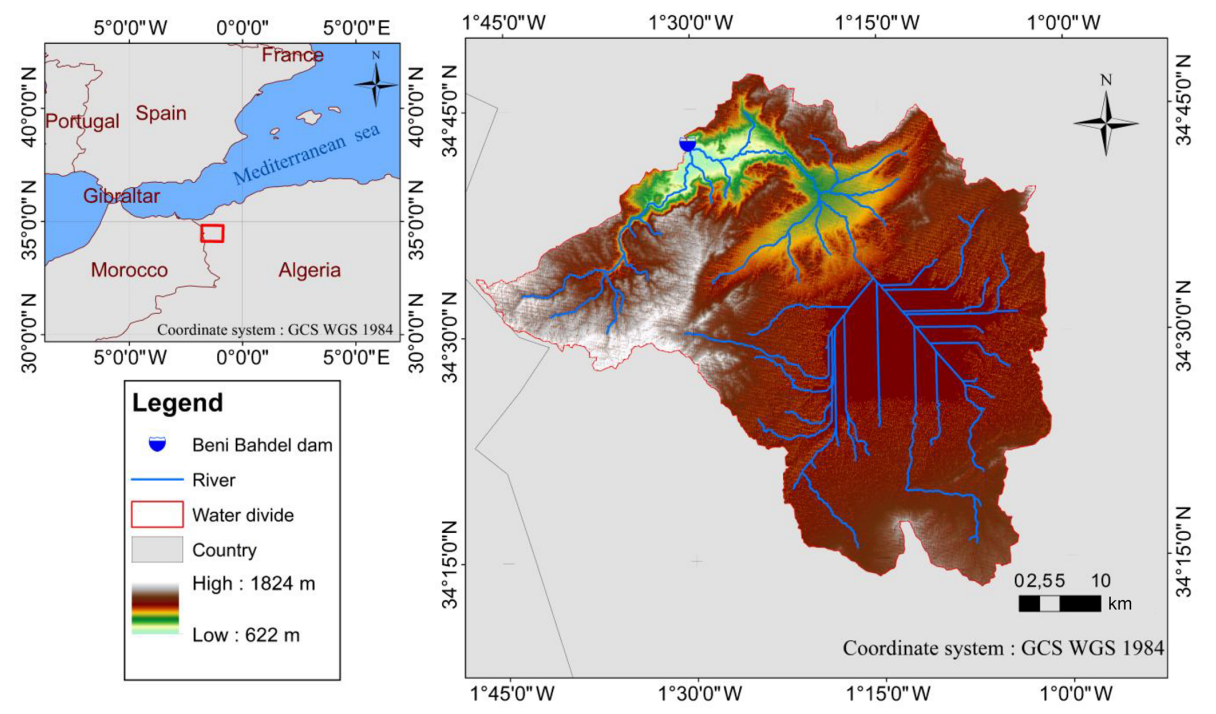

Figure 1. Location of the Beni Bahdel Dam catchment.

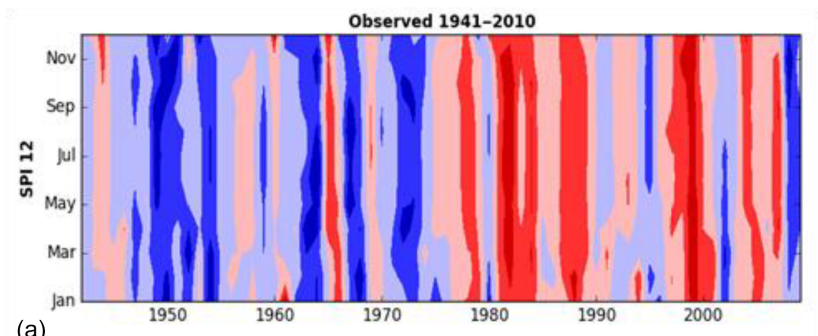

(a)

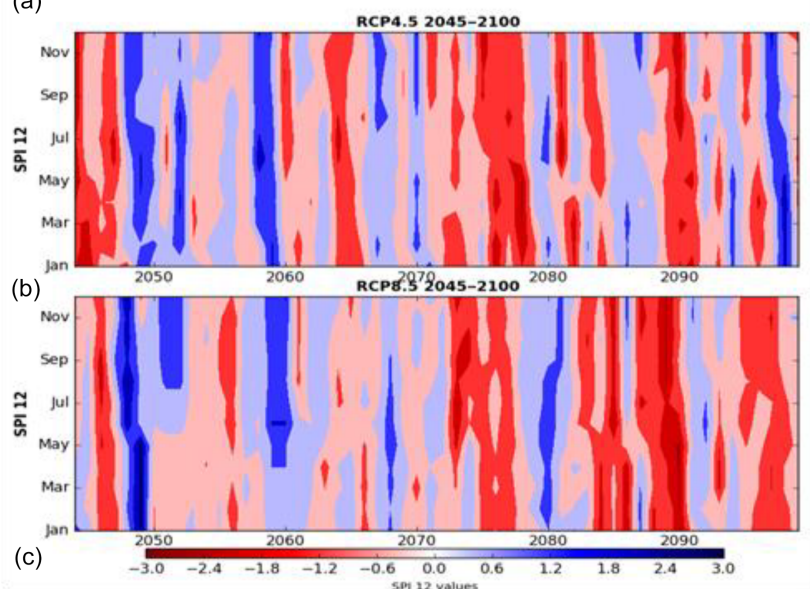

Figure 2. Temporal variation of meteorological drought (SPI 12) in the Beni Bahdel Dam catchment. (a) SPI-12 derived from observed precipitation (1941-2010), and (b, c) SPI-12 derived from the projected precipitation by the RCA4-MPI-ESM-LR climate model for the RCP4.5 and RCP8.5 scenario, respectively, period 2045-2100.
$36 \%$. The maximum duration is expected to hardly change under the RCP8.5 scenario (58 months) or even to decline (RCP4.5).

The future SPI-12 are presented in Fig. $2 \mathrm{~b}$ and $\mathrm{c}$ for the two RCP scenarios. Results show that the drought severity and duration likely will intensify in the future period, especially under the RCP8.5 scenario.

\section{Conclusions}

The temporal evolution of drought events using the SPI12 was analyzed for the period from 1941 to 2100 in the Beni Bahdel Dam catchement situated in the Northwest of Algeria. The SPI12 was calculated from the oberved rainfall (1941-2005) and from the RCA4-MPI-ESM-LR climate model (1951-2100). The SPI-12 derived from the observations shows that there has been a clear drying trend in the past, particularly since the mid 1970s. The climate model predicts an increase of the mean number, severity and the duration of the drought events in the future under the most pessimistic scenario of greenhouse gas emissions (RCP8.5). Under the RCP4.5 scenario the drought is projected to remain about the same, or even will become less extreme. The current drought episodes experienced in the Beni Bahdel basin and the anticipated increase of these dry trends in the future under the extreme emissions sceanrio will cause numerous challenges, particularly to esnure food safety in Algeria. This finding must be taken into account in the elaboration of future socio-economic plans of the developement.

Data availability. The in-situ data are provided from the Algerian National Agency of Water Resources (ANRH). The projected data from RCA4-MPI-ESM-LR are provided from Coordi- 
nated Regional climate Downscaling Experiment modeling groups over Africa https://esg-dn1.nsc.liu.se/search/cordex/ (last access: 23 June 2018) (SMHI, 2018).

Author contributions. BS, ZA and MM made the conceptualization of the work; BS and ZA done the methodology. BS done the data analysis; wrote the codes and the original draft; have made the review and editing of the paper. ZA supervised the work and participated in writing-review and editing. MM supervised and presented the work in Beijing during the 8th Global FRIEND-Water Conference: Hydrological Processes and Water Security in a Changing World. DF helped in the data treatment and analysis. AR provided climate model projections and bias correction; and supervised the work.

Competing interests. The authors declare that they have no conflict of interest.

Special issue statement. This article is part of the special issue "Hydrological processes and water security in a changing world". It is a result of the 8th Global FRIEND-Water Conference: Hydrological Processes and Water Security in a Changing World, Beijing, China, 6-9 November 2018.

Acknowledgements. The authors wish to thank the National Agency of Water Resources (ANRH) of Algeria for providing the data on which reported analyses are based. We acknowledge the World Climate Research Program's Working Group on Regional Climate the CORDEX-Africa (Coordinated Regional climate Downscaling Experiment), initiative of the CMIP5 project for the World Climate Research Program. We also thank the Rossby Center for producing and making available their regional atmospheric model, RCA4 output. Lastly, we thank the reviewers for their constructive comments.

\section{References}

Achour, K., Meddi, M., Zeroual, A., Bouabdelli, S., Maccioni, P., and Moramarco, T.: Spatio-temporal analysis and forecasting of drought in the plains of northwestern Algeria using the standardized precipitation index, J. Earth Syst. Sci., 129, 42, https://doi.org/10.1007/s12040-019-1306-3, 2020.

Alderlieste, M. A. A., Van Lanen, H. A. J., and Wanders, N.: Future low flows and hydrological drought: How certain are these for Europe?, IAHS-AISH Proc. Rep., 363, 60-65, 2014.

Bouabdelli, S., Meddi, M., Zeroual, A., and Alkama, R.: Hydrological drought risk recurrence under climate change in the karst area of Northwestern Algeria, J. Water Clim. Change, https://doi.org/10.2166/wcc.2020.207, in press, 2020.

Brunet, M., Jones, P. D., Sigró, J., Saladié, O., Aguilar, E., Moberg, A., Della-Marta, P. M., Lister, D., Walther, A., and López, D.: Temporal and spatial temperature variability and change over Spain during 1850-2005, J. Geophys. Res.-Atmos., 112, D12117, https://doi.org/10.1029/2006JD008249, 2007.
Christensen, J. H., Hewitson, B., Busuioc, A., Chen, A., Gao, X., Held, R., Jones, R., Kolli, R. K., Kwon, W. K., Laprise, R., Magana Rueda, V., Mearns, L., Menendez, C. G., Räisänen, J., Rinke, A., Sarr, A., Whetton, P., Arritt, R., Benestad, R., Beniston, M., Bromwich, D., Caya, D., Comiso, J., de Elia, R., and Dethloff, K.: Regional climate projections. Climate Change, 2007: The Physical Science Basis, in: chap. 11, Contribution of Working group I to the Fourth Assessment Report of the Intergovernmental Panel on Climate Change, Cambridge University Press, Cambridge, 847-940, 2007.

Dracup, J. A., Lee, K. S., and Paulson, E. G.: On the definition of droughts, Water Resour. Res., 16, 297-302, https://doi.org/10.1029/WR016i002p00297, 1980.

Giorgi, F., Jones, C., and Asrar, G. R.: Addressing climate information needs at the regional level: the CORDEX framework, Bull.World Meteorol. Organ., 58, 175-183, 2009.

Jones, C., Giorgi, F., and Asrar, G.: The Coordinated Regional Downscaling Experiment: CORDEX - an international downscaling link to CMIP5, Clivar Exch., 56, 34-40, 2011.

Khan, S., Gabriel, H. F., and Rana, T.: Standard precipitation index to track drought and assess impact of rainfall on watertables in irrigation areas, Irrig. Drain. Syst., 22, 159-177, https://doi.org/10.1007/s10795-008-9049-3, 2008.

Marcos-Garcia, P., Lopez-Nicolas, A., and Pulido-Velazquez, M.: Combined use of relative drought indices to analyze climate change impact on meteorological and hydrological droughts in a Mediterranean basin, J. Hydrol., 27, R713-R715, https://doi.org/10.1016/j.jhydrol.2017.09.028, 2017.

Mckee, T. B., Doesken, N. J., and Kleist, J.: The relationship of drought frequency and duration to time scales, Water, 179, 1722, 1993.

Meddi, M., Assani, A. A., and Meddi, H.: Temporal Variability of Annual Rainfall in the Macta and Tafna Catchments, Northwestern Algeria, Water Resour. Manage., 24, 3817-3833, https://doi.org/10.1007/s11269-010-9635-7, 2010.

Shiau, J. T.: Fitting drought duration and severity with twodimensional copulas, Water Resour. Manage., 20, 795-815, https://doi.org/10.1007/s11269-005-9008-9, 2006.

SMHI - Swedish Meteorological and Hydrological Institute: ESGF@LiU/CORDEX, available at: https://esg-dn1.nsc.liu.se/ search/cordex/, last access: 23 June 2018.

Teutschbein, C. and Seibert, J.: Bias correction of regional climate model simulations for hydrological climate-change impact studies: Review and evaluation of different methods, J. Hydrol., 456457, 12-29, https://doi.org/10.1016/j.jhydrol.2012.05.052, 2012.

Zeroual, A., Assani, A. A., and Meddi, M.: Combined analysis of temperature and rainfall variability as they relate to climate indices in Northern Algeria over the 1972-2013 period, Hydrol. Res., 48, 584-595, https://doi.org/10.2166/nh.2016.244, 2017.

Zeroual, A., Assani, A. A., Meddi, M., and Alkama, R.: Assessment of climate change in Algeria from 1951 to 2098 using the Köppen-Geiger climate classification scheme, Clim. Dynam., 52, 227-243, https://doi.org/10.1007/s00382-018-4128-0, 2019. 